\title{
REKONSTRUKSI KETAHANAN SOSIAL MELALUI PENCIPTAAN RUANG PUBLIK DI KOTA NAMLEA
}

M Chairul Basrun Umanailo ${ }^{1}$, Annisa Retrofilia Umanailo ${ }^{1}$, and Askar Daffa Sophia Umanailo $^{1}$

${ }^{1}$ Affiliation not available

January 4, 2021

\section{Hosted file}

RKS.pdf available at https://authorea.com/users/310886/articles/500573-rekonstruksiketahanan-sosial-melalui-penciptaan-ruang-publik-di-kota-namlea 